\title{
hTERT, MYC and TP53 deregulation in gastric preneoplastic lesions
}

\author{
Tanielly Cristina Raiol Silva ${ }^{1 \dagger}$, Mariana Ferreira Leal ${ }^{2^{*} \dagger}$, Danielle Queiroz Calcagno ${ }^{2}$, \\ Carolina Rosal Teixeira de Souza ${ }^{1}$, André Salim Khayat ${ }^{1}$, Ney Pereira Carneiro dos Santos ${ }^{3}$, \\ Raquel Carvalho Montenegro', Silvia Helena Barem Rabenhorst ${ }^{4}$, Mayara Quaresma Nascimento', \\ Paulo Pimentel Assumpção ${ }^{3}$, Marília de Arruda Cardoso Smith ${ }^{2}$ and Rommel Rodríguez Burbano ${ }^{1}$
}

\begin{abstract}
Background: Gastric cancer is a serious public health problem in Northern Brazil and in the world due to its high incidence and mortality. Despite the severity of the disease, more research is needed to better understand the molecular events involved in this intestinal-type gastric carcinogenesis process. Since precancerous lesions precede intestinal-type gastric cancer, here, we evaluated the hTERT, MYC, and TP53 mRNA and protein expression, as well as TP33 copy number, in gastric preneoplastic lesions.

Methods: We evaluated 19 superficial gastritis, 18 atrophic gastritis, and 18 intestinal metaplasia from cancer-free individuals of Northern Brazil. Quantitative reverse transcription PCR was used to analyze the mRNA expression and immunohistochemical methods were used to assess protein immunoreactivity in tissue samples. The number of TP53 gene copies was investigated in gastric diseases by quantitative PCR.

Results: We observed hTERT, MYC, and p53 immunoreactivity only in intestinal metaplasia samples. The immunoreactivity of these proteins was strongly associated with each other. A significantly higher MYC mRNA expression was observed in intestinal metaplasia compared to gastritis samples. Loss of TP53 was also only detected in intestinal metaplasia specimens.
\end{abstract}

Conclusions: We demonstrated that hTERT, MYC, and TP53 are deregulated in intestinal metaplasia of individuals from Northern Brazil and these alterations may facilitate tumor initiation.

Keywords: hTERT, MYC, TP53, Gastric carcinogenesis, Precancerous lesions

\section{Background}

Gastric cancer is the fourth most common cancer and the second leading cause of cancer-related death worldwide [1]. In Northern Brazil, gastric cancer is the second most frequent neoplasia among males and the third in females [2]. Some histopathological lesions precede welldifferentiated or intestinal-type gastric cancer. These neoplasia types progress through a number of sequential steps beginning with superficial gastritis, followed by chronic atrophic gastritis, intestinal metaplasia, intraepithelial neoplasia, and finally, carcinoma [3]. Although

\footnotetext{
* Correspondence: mariana.morf@epm.br

${ }^{\dagger}$ Equal contributors

2Disciplina de Genética, Departamento de Morfologia e Genética,

Universidade Federal de São Paulo, Rua Botucatu 740, CEP 04023-900, São

Paulo, SP, Brazil

Full list of author information is available at the end of the article
}

this neoplasia is a serious public health problem in Northern Brazil and in the world, little is known about the molecular events involved in the gastric carcinogenesis process. A better understanding of the critical alterations implicated in tumor initiation is necessary to reduce the mortality rates through early diagnosis and treatment.

Cell immortalization has been reported as an important event in carcinogenesis. This process requires activation of telomerase, an enzyme essential for stabilizing telomere length. Telomerase activation is described in about $90 \%$ of human cancers, while most normal tissues contain inactivated telomerase [4]. In the absence of genome checkpoint functions, telomere dysfunction accelerates genomic instability, facilitating tumor initiation [5]. This genomic instability caused by telomere dysfunction 
occurs in the early stages of carcinogenesis, before telomerase activation. Subsequently, telomeres in these initiated cells undergo further progressive shortening, generating rampant chromosomal instability and threatening cell survival. Telomerase activation occurs at this stage to stabilize the genome and confer unlimited proliferative capacity upon the emerging and evolving cancer cell. Therefore, cells that have acquired telomerase activity can obtain the capacity for cancer progression [6].

Transcriptional regulation of hTERT (the catalytic subunit of telomerase) gene is the major mechanism for cancer-specific activation of telomerase. Several factors have been reported to directly or indirectly regulate the hTERT promoter, including cellular transcriptional activators, such as MYC, as well as the repressors, such as p53 (see review [6]).

The $M Y C$ proto-oncogene has been described as a key in the gastric carcinogenic process [7]. MYC protein has an effect on about $15 \%$ of genes in the human genome [8]. MYC activates several genes involved in cell cycle regulation, metabolism, ribosome biogenesis, protein synthesis, and mitochondrial function, while it consistently represses genes involved in cell growth arrest and cell adhesion, and also has a direct role in the control of DNA replication [9]. Among the $M Y C$ target genes are hTERT as well as TP53 [9].

TP53 is a key tumor suppressor gene in the carcinogenesis process [10] acting in the DNA damage response and apoptosis, as well as a regulator of cell metabolism [11]. TP53 somatic alteration is described in approximately $50 \%$ of human cancers, including gastric cancer [10]. Moreover, the loss of the TP53 locus is a common finding in gastric neoplasias of individuals from Northern Brazil [12].

The aim of the present study was to determine whether hTERT, MYC, and TP53 mRNA expression, as well as their protein products, are deregulated in gastric preneoplastic lesions from cancer-free individuals of Northern Brazil. The number of TP53 gene copies was also evaluated in gastric diseases.

\section{Results}

hTERT, MYC, and p53 immunostaining was only detected in intestinal metaplasia samples (Figure 1, Table 1). The frequency of hTERT $\left(x^{2}=19.243, \mathrm{df}=2, \mathrm{p}<0.001\right.$, by Pearson Chi-square, $\mathrm{V}=0.592)$, MYC $\left(\chi^{2}=19.243, \mathrm{df}=2, \mathrm{p}<0.001\right.$, $\mathrm{V}=0.592)$, and $\mathrm{p} 53\left(\mathrm{x}^{2}=13.844, \mathrm{df}=2, \mathrm{p}=0.001, \mathrm{~V}=0.502\right)$ immunoreactivity differed among groups (Table 1$)$. Using the Bonferroni correction, a series of Fisher exact tests demonstrated that the frequency of hTERT ( $\mathrm{p}=0.001, \mathrm{OR}=$ 1.9), MYC ( $\mathrm{p}=0.001, \mathrm{OR}=1.9)$, and $\mathrm{p} 53(\mathrm{p}=0.01, \mathrm{OR}=$ 1.58) immunoreactivity was higher in intestinal metaplasia than in superficial gastritis. Intestinal metaplasia samples also presented a higher frequency of hTERT $(\mathrm{p}=0.001$,
$\mathrm{OR}=1.8)$, MYC $(\mathrm{p}=0.001, \mathrm{OR}=1.8)$, and $\mathrm{p} 53(\mathrm{p}=0.008$, $\mathrm{OR}=1.5)$ immunoreactivity compared to atrophic gastritis specimens. hTERT was strongly associated with MYC $\left(\mathrm{X}^{2}=40.086, \mathrm{df}=1, \mathrm{p}<0.001, \mathrm{~V}=0.854, \mathrm{OR}=0.024\right)$ and p53 $\left(\chi^{2}=39.566, d f=1, p<0.001, V=0.848, \quad O R=0.041\right)$ immunoreactivity. MYC and p53 immunoreactivity was also strongly associated $\left(\chi^{2}=25.638, \mathrm{df}=1, \mathrm{p}<0.001\right.$, $\mathrm{V}=0.683$, OR $=0.073)$. Five of $18(27.8 \%)$ intestinal metaplasia samples presented immunoreactivity for the three studied proteins.

We observed a significant difference in $M Y C$ $\left(\mathrm{F}={ }_{2,52}=41.172, \mathrm{p}<0.001\right.$, by ANOVA test, $\left.\eta^{2}=0.613\right)$ mRNA expression among the studied groups (Table 1). Tukey post-hoc analyses revealed that MYC mRNA expression was higher in intestinal metaplasia than superficial $(\mathrm{p}<0.001)$ and atrophic $(\mathrm{p}<0.001)$ gastritis. A 1.5-fold increase in $M Y C$ expression was detected in $83.3 \%$ of intestinal metaplasia samples. The $M Y C$ mRNA expression tended to be higher in samples with $\mathrm{H}$. pylori than samples without this pathogen $\left(\mathrm{T}_{53}=-1.934\right.$, $\mathrm{p}=0.058$, by Student test, $\mathrm{r}=0.257) . M Y C$ and TP53 mRNA expression were not correlated $(\mathrm{p}=0.334$, $\mathrm{r}=0.133)$. hTERT was weakly correlated to $M Y C$ and TP53 mRNA expression $(\mathrm{p}=0.047, \mathrm{r}=0.267 ; \mathrm{p}=0.028$, $\mathrm{r}=0.296$, respectively).

Higher hTERT and MYC mRNA expression was associated with MYC immunoreactivity $\left(\mathrm{T}_{53}=-3.218, \mathrm{p}=0.002\right.$, by Student test, $\mathrm{r}=0.398 ; \mathrm{T}_{53}=--7.429, \mathrm{p}<0.001$, $\mathrm{r}=0.701$, respectively). Higher hTERT, MYC, and TP53 mRNA expression was associated with hTERT $\left(\mathrm{T}_{53}=-3.658, \mathrm{p}=0.001, \mathrm{r}=0.442 ; \mathrm{T}_{53}=-5.88, \mathrm{p}<0.001\right.$, $\mathrm{r}=0.621 ; \mathrm{T}_{53}=-2.316, \mathrm{p}=0.024 ; \mathrm{r}=0.298$, respectively) and $\mathrm{p} 53 \quad\left(\mathrm{~T}_{53}=-2.495, \quad \mathrm{p}=0.016, \quad \mathrm{r}=0.319 ; \quad \mathrm{T}_{53}=-4.64\right.$, $\mathrm{p}<0.001, \mathrm{r}=0.530 ; \mathrm{T}_{53}=-2.674, \mathrm{p}=0.010 ; \mathrm{r}=0.339$, respectively) immunoreactivity.

One sample of superficial gastritis presented 3 copies of TP53 and this case was excluded from the CNV statistical analyses. Loss of TP53 copies was observed only in the group of intestinal metaplasia samples (Table 1). The frequency of TP53 loss was significantly higher in intestinal metaplasia samples compared to gastritis specimens $\left(x^{2}=6.353, d f=1, p=0.033\right.$, by Fisher exact test, $V=0.343$, $\mathrm{OR}=2.4)$. The loss of TP53 copies was associated with hTERT $\left(\chi^{2}=18.265, \mathrm{df}=1, \mathrm{p}=0.002, \mathrm{~V}=0.582\right.$; $\mathrm{OR}=1.6$ ) and $\mathrm{p} 53\left(\mathrm{X}^{2}=9.926, \mathrm{df}=1, \mathrm{p}=0.03, \mathrm{~V}=0.429, \mathrm{OR}=1.47\right)$ immunoreactivity. However, this analysis should be considered with care since only 3 cases presented loss of TP53 copies.

\section{Discussion}

Telomerase activation is thought to be essential for the stabilization of telomere length, through which immortalization and oncogenesis are achieved, but little is known about the regulation of the hTERT subunit in 

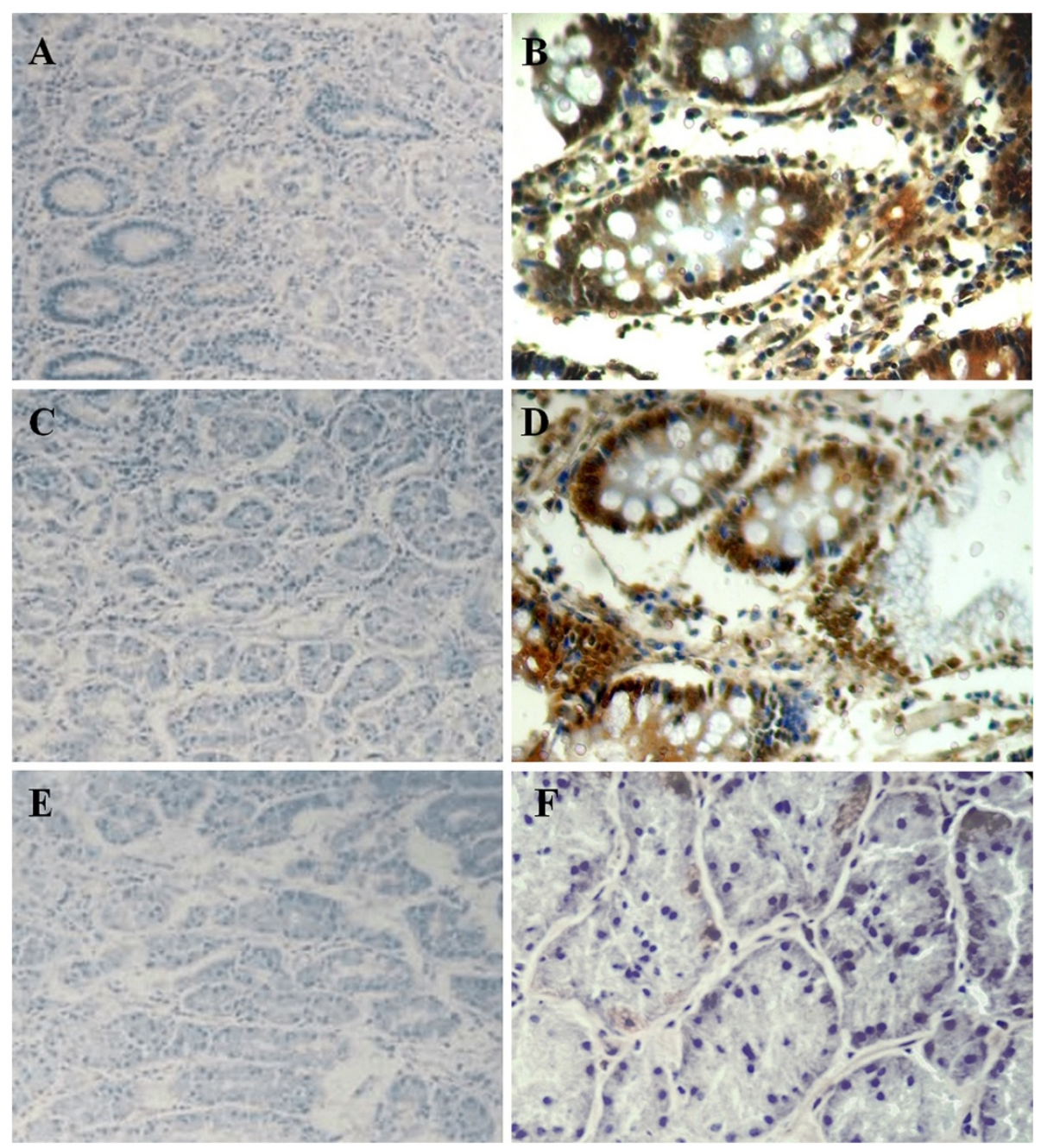

Figure 1 Immunostaining of hTERT, MYC and p53. (A) Absence of hTERT staining in atrophic gastritis (100x); (B) hTERT immunoreactivity in intestinal metaplasia (400X); (C) Atrophic gastritis without MYC immunoreactivity (100x); (D) MYC immunopositivity in intestinal metaplasia (400X); (E) Absence of p53 immunoreactivity in atrophic gastritis (100x); (F) negative control (400x).

human precancerous gastric lesions. In the present study, we observed that hTERT, MYC, and p53 immunoreactivity was only present in intestinal metaplasia samples. In addition, we detected a strong association among these three proteins and $27.8 \%$ of intestinal metaplasia samples presented immunostaining of the three studied proteins. MYC is a transcriptional activator and p53 is a repressor of $h T E R T$ expression [6]. Some studies favored the view that MYC drove initial proliferation and subsequent differentiation, concomitant with the activation of the p53 G2 checkpoint and also demonstrated that inactivation of the $\mathrm{p} 53-\mathrm{Rb}$ pathway is required for immortalization through overepression of MYC $[13,14]$. Thus, some cases of intestinal metaplasia may carry short telomeres and due to this telomere dysfunction, MYC stimulates hTERT expression. However, in the absence of genome checkpoint functions (i.e. p53 mutations or TP53 deletion), this process will favor the proliferation of immortalized cells carrying genetic and epigenetic alterations and tumor initiation.

It is important to note that, although intestinal metaplasia precedes intestinal-type gastric cancer, only few individuals with this preneoplastic lesion will develop gastric tumors. Further investigation are necessary to evaluate the role of hTERT, MYC, and p53 proteins alterations common described in gastric neoplasia - in the disease progression, ideally with biopsies of intestinal metaplasia and tumor from the same patients. These biomarkers may be useful for the assessment of gastric cancer risk if validated in a larger clinical study sets.

Some studies demonstrated that hTERT expression increases with the sequential steps of intestinal-type gastric carcinogenesis [15-19], suggesting that hTERT deregulation represents an important step in the 
Table 1 Clinicopathological characteristics, MYC, hTERT and TP53 expression, and TP53 copies in gastric samples

\begin{tabular}{|c|c|c|c|}
\hline & Superficial gastritis & Atrophic gastritis & Intestinal metaplasia \\
\hline \multicolumn{4}{|l|}{ Gender } \\
\hline Male [N (\%)] & $12(63.2)$ & $11(61.1)$ & $12(66.7)$ \\
\hline Female [N (\%)] & $7(36.8)$ & $7(38.9)$ & $6(33.3)$ \\
\hline \multicolumn{4}{|c|}{ Alcohol consumption } \\
\hline Negative [N (\%)] & $10(52.6)$ & $10(55.6)$ & $12(66.7)$ \\
\hline Positive [N (\%)] & $9(47.4)$ & $8(44.4)$ & $6(33.3)$ \\
\hline \multicolumn{4}{|c|}{ Cigarette smoking } \\
\hline Negative [N (\%)] & $10(52.6)$ & $12(66.7)$ & $9(50)$ \\
\hline Positive* [N (\%)] & $9(47.4)$ & $6(33.3)$ & $9(50)$ \\
\hline \multicolumn{4}{|c|}{ H. pylori infection } \\
\hline Negative [N (\%)] & $7(36.8)$ & $5(27.8)$ & $1(5.6)$ \\
\hline Positive [N (\%)] & $12(63.2)$ & $13(72.2)$ & $17(94.4)$ \\
\hline \multicolumn{4}{|c|}{ hTERT mRNA expression } \\
\hline RQ (Mean $\pm S D)$ & $1.092 \pm 0.61$ & $0.821 \pm 0.47$ & $1.184 \pm 0.55$ \\
\hline \multicolumn{4}{|c|}{ MYC mRNA expression } \\
\hline RQ (Mean $\pm S D)$ & $0.852 \pm 0.51^{* *}$ & $0.873 \pm 0.28^{* *}$ & $1.901 \pm 0.49$ \\
\hline \multicolumn{4}{|c|}{ TP53 mRNA expression } \\
\hline RQ (Mean $\pm S D)$ & $0.997 \pm 0.59$ & $0.847 \pm 0.79$ & $1.021 \pm 0.61$ \\
\hline \multicolumn{4}{|c|}{ hTERT immunoreactivity } \\
\hline Negative [N (\%)] & $19(100)$ & $18(100)$ & $10(55.6)$ \\
\hline Positive [N (\%)] & $0(0)^{* *}$ & $0(0)^{* *}$ & $8(44.4)$ \\
\hline \multicolumn{4}{|c|}{ MYC immunoreactivity } \\
\hline Negative [N (\%)] & $19(100)$ & $18(100)$ & $10(55.6)$ \\
\hline Positive [N (\%)] & $0(0)^{* *}$ & $0(0)^{* *}$ & $8(44.4)$ \\
\hline \multicolumn{4}{|c|}{ p53immunoreactivity } \\
\hline Negative [N (\%)] & $19(100)$ & $18(100)$ & $12(66.7)$ \\
\hline Positive [N (\%)] & $0(0)^{* *}$ & $0(0)^{* *}$ & $6(33.3)$ \\
\hline \multicolumn{4}{|l|}{ TP53 copies } \\
\hline 2 copies [N (\%)] & $18(100)$ & $18(100)$ & 15 (83.3) \\
\hline 1 copy [N (\%)] & $0(0)$ & $0(0)$ & $3(16.7)^{* * *}$ \\
\hline
\end{tabular}

$\mathrm{RQ}$ : relative quantification.

*Patients smoking one or more cigarettes per day (range 1-20).

**Significantly different from intestinal metaplasia group.

***Gastritis was significantly different from intestinal metaplasia group.

carcinogenesis progress. We also previously demonstrated that $80 \%$ of gastric tumors and no nonneoplastic gastric mucosa of individuals from Northern Brazil presented hTERT immunoreactivity, suggesting that hTERT may have an impact on the anti-telomerase strategy for cancer therapy [20].

The detection of MYC immunoreactivity in intestinal metaplasia of individuals from three Northern Brazil populations corroborates previous studies of our group that demonstrated the presence of MYC protein overexpression only in intestinal metaplasia and neoplastic tissue from all patients with intestinal type gastric cancer, which is preceded by preneoplastic lesions [21-23], as well as in intestinal metaplasia of non-human primates treated with N-methyl-nitrosourea (MNU) [24]. On the other hand, MYC immunoreactivity was described in gastritis samples, as well as intestinal metaplasia, in Asian populations [15,25-27].

Here, MYC immunoreactivity was strongly associated with increased mRNA expression. To our knowledge, this is the first study to sensitively quantify $M Y C$ mRNA expression in precancerous gastric lesions. The increased MYC expression in intestinal metaplasia supports a previous study of our group in non-human primates, in 
which we demonstrated a continuous increase of $M Y C$ mRNA expression during the sequential steps of gastric carcinogenesis in MNU-treated animals [24]. In these animals, the mRNA expression increased about 3-fold in intestinal metaplasia compared to normal gastric mucosa. In addition, we previously reported that a significant increase of $M Y C$ copy number was seen with the evolution of carcinogenesis process in humans and nonhuman primates $[21,24]$, which may contribute to the increased mRNA expression and protein immunoreactivity. In addition, $M Y C$ amplification or trisomy of chromosome 8, where $M Y C$ is located, was detected in all human gastric cancer of individuals from Northern Brazil [21-23,28-31], as well as in gastric cancer cell lines established from the tumors of Brazilian patients [32-35], supporting that $M Y C$ has a key role in gastric carcinogenesis.

Previously we also reported the presence of p53 immunoreactivity in all intestinal-type gastric cancer of individuals from Northern Brazil [12]. The p53 immunoreactivity usually depends on the accumulation of mutated p53 proteins in the cell, which leads to a longer half-life [36]. Some studies have demonstrated TP53 mutations in gastritis [37] and intestinal metaplasia $[38,39]$ as well as gastric cancer, which corroborates the observation of p53 immunoreactivity in intestinal metaplasia samples of the studied population. The presence of p53 immunostaining only in intestinal metaplasia corroborates previous studies of literature $[15,40]$. However, Targa et al. [41] reported p53 overexpression in 5/19 (26.3\%) of chronic gastritis, $1 / 8(12.5 \%)$ of atrophic gastritis and 2/11 (18.2\%) of intestinal metaplasia of individuals from Southeastern Brazil.

To our knowledge, few studies evaluated the number of copies of TP53 in pre-neoplastic gastric lesions. Loss of heterozygosity at the TP53 locus is one of the most common mechanisms involved in this gene pathway deregulation. Loss of TP53 is a frequent finding in gastric cancer [42]. Previously, our group demonstrated that the loss of TP53 copies and aneusomy of chromosome 17, where this gene is located, was present in all gastric cancer samples of individuals from Pará State, Northern Brazil [12], and also in all gastric cancer cell lines established from neoplasias in this population $[33,43]$. Here, we observed TP53 deletion in $16.7 \%$ of intestinal metaplasia in individuals from Northern Brazil by qPCR. In a Southeastern Brazilian population, it was described that $3 / 5(60 \%)$ of intestinal metaplasia samples presented loss of TP53 by fluorescence in situ hybridization (FISH) assay [36]. Williams et al. [42] also reported that the deletion of TP53 was a common event in premalignant stages of gastric carcinogenesis by FISH analyses. These authors demonstrated that this alteration was about 3fold increased in intestinal metaplasia $(\mathrm{N}=4)$ compared to normal gastric tissue. Since TP53 is a critical tumor suppressor gene in the carcinogenesis process, the loss of this gene copy and its protein immunoreactivity in the intestinal metaplasia stage may contribute for tumor initiation.

\section{Conclusions}

In conclusion, hTERT, MYC, and TP53 are deregulated in intestinal metaplasia of individuals from Northern Brazil and these alterations may facilitate tumor initiation.

\section{Methods}

\section{Clinical samples}

Samples were obtained from cancer-free patients including 19 with superficial gastritis, 18 with atrophic gastritis, and 18 patients with intestinal metaplasia by endoscopy. From each patient, normal tissue sample were also collected. Samples were collected at endoscopy services in Pará, Maranhão and Ceará States in Northern Brazil. Informed consent with approval of the ethics committee of the Federal University of Pará was obtained. Tissue specimens were immediately frozen in liquid nitrogen and kept at $-80^{\circ} \mathrm{C}$ until RNA and DNA extraction. All studied samples were negative for Epstein-Barr infection by in situ hybridization method [44]. The presence of Helicobacter pylori, a class I carcinogen, in gastric samples was detected by the PCR assay for the urease gene [45]. Table 1 shows the clinicopathological characteristics of patients.

\section{Immunohistochemistry}

Immunohistochemical analyses were performed on formalin-fixed, paraffin-embedded sections. Immunohistochemical staining was performed on the paraffin sections according to Calcagno et al. [22] with primary mouse monoclonal antibody against hTERT (dilution 1:50; clone 44 F12, Novocastra Laboratories Ltd, UK), MYC (dilution 1:150; sc-40, Santa Cruz Biotechnology, USA and Zymed ${ }^{\circledR}$, USA), or p53 (dilution 1:50; Dakocytomation, USA). A universal peroxidase-conjugated secondary antibody kit (LSAB System, DakoCytomation, USA) was used for the detection system, and diaminobenzidine (DAB) was the applied chromogen. Positive protein expression was defined as clear nuclear imunostaining in more than $10 \%$ of the cells.

\section{mRNA expression}

Total RNA was extracted with Tri-reagent (Applied Biosystems, USA) following the manufacturer's instructions. RNA concentration and quality were determined using the NanoDrop spectrophotometer (Kisker, Germany) and $1 \%$ agarose gels. Complementary DNA was synthesized using High-Capacity cDNA Archive (Applied Biosystems, Poland). 
hTERT, MYC, and TP53 mRNA expression was evaluated by quantitative reverse transcription PCR (qRTPCR) with primers and TaqMan probes purchased as Assays-on-demand Products for Gene Expression (Applied Biosystems, USA). GAPDH gene was selected as an internal control for RNA input and reverse transcription efficiency. All real-time qRT-PCR reactions were performed in triplicate for all target genes (hTERT: Hs00972656_m1; MYC: Hs00153408_m1; TP53: Hs01034249_m1) and the internal control (GAPDH: NM_002046.3).

Relative quantification (RQ) of the gene expression was calculated according to Livak and Schmittgen [46]. In the present study, the corresponding normal tissue sample was designated as a calibrator for superficial gastritis, atrophic gastritis, or intestinal metaplasia sample from each patient.

\section{TP53 copy number variation (CNV)}

Quantitative TaqMan CNV assays (Applied Biosystems, USA) were used as a confirmation to FISH analysis. Duplex quantitative PCR (qPCR) was performed using the FAM/MGB-labeled TaqMan probe for TP53 gene (Hs06423639_cn) and VIC/TAMRA-labeled TaqMan CNV RNAse P (\#4403326) for the internal control. qPCR reactions were performed in quadruplicate with genomic DNA (gDNA) according to the manufacturer's protocol and cycling conditions in 7500 Fast Real-Time PCR (Applied Biosystems, USA). Relative quantification analysis was done to estimate the copy number for each sample by using the Copy Caller Software V1.0 (Applied Biosystems, USA). A known human gDNA (Promega, USA) was used for calibration.

\section{Data analysis}

Chi-square test was performed to analyze hTERT, MYC, and p53 immunostaining, as well as TP53 CNV data. To take into account the multiple testing, Bonferroni corrections were applied to adjust the Chi-squared $\mathrm{p}$ value when necessary. Shapiro-Wilk normality test was used to evaluate the normal distribution of mRNA expression data and to determine subsequent use of appropriate tests for statistical comparison. Data that were not normally distributed were transformed (z-score transformation) for the analysis of variance in gene expression such that they followed a normal distribution. Analyses of variance in mRNA expression were performed by one-way ANOVA followed by Tukey (homogeneity of variances according to Levene test) post-hoc test. Chisquare and Student's T test were used to assess the relationship between gene expression, protein immunoreactivity, and $\mathrm{CNV}$ results and clinicopathological factors.

The effect size for Chi-square was based on Cramer's phi (V) and the effect size correlation directly from the
Student T test as "r" (Pearson correlation coefficient), in which a value between 0.1-0.29 was determined as a small effect size; 0.3-0.49 as a medium effect size; and 0.50 or above as a large effect size. The effect size for ANOVA analyses was based on Eta Squared $\left(\eta^{2}\right)$, in which values 0.15 and below were determined as a small effect size; $0.16-0.40$ as a medium effect size; and above 0.40 as a large effect size.

The correlation between hTERT, MYC, and TP53 mRNA expression was analyzed by the Pearson test, in which a value below 0.30 was determined as a weak correlation; $0.30-0.70$ as a medium correlation; and above 0.70 as a strong correlation.

In all analyses, the confidence interval was $95 \%$ and $p$ values less than 0.05 were considered significant.

\section{Abbreviations}

CNV: Copy Number Variation; DAB: diaminobenzidine; gDNA: genomic DNA; MNU: Nmethyl-nitrosourea; $\mathrm{APCR}$ : quantitative PCR; qRT-PCR: quantitative reverse transcription PCR; RQ: Relative Quantification.

\section{Competing interests}

All authors declare that they have no conflicts of interest.

\section{Authors' contributions}

MFL, TCRS, PPA, MACS and RRB conceived and designed the experiments. TCRS, MFL, DQC, RCM and MQN performed the experiments. TCRS, MFL, DQC, CRT, ASK, NPCS, MACS, and RRB analyzed the data. NPCS, SHBR and PPA contributed reagents/materials/analysis tools. MFL, TCRS, MACS and RRB wrote the paper. All authors read and approved the final manuscript.

\section{Acknowledgements}

This study was supported by the Conselho Nacional de Desenvolvimento Científico e Tecnológico (www.cnpq.br) grant number 302774/2009-2 to RRB and 301609/2007-1 to MACS and by the Fundação de Amparo à Pesquisa do Estado de São Paulo (www.fapesp.br) to MFL and DQC.

\section{Author details}

'Laboratório de Citogenética Humana, Instituto de Ciências Biológicas, Universidade Federal do Pará, CEP: 66073-000, Belém, PA, Brazil. 'Disciplina de Genética, Departamento de Morfologia e Genética, Universidade Federal de São Paulo, Rua Botucatu 740, CEP 04023-900, São Paulo, SP, Brazil.

${ }^{3}$ Unidade de Alta Complexidade em Oncologia, Hospital Universitário João de Barros Barreto, Universidade Federal do Pará, CEP: 60673-000, Belém, PA Brazil. " Laboratório de Genética Molecular, Departamento de Patologia e Medicina Forense, Escola de Medicina, Universidade Federal do Ceará, CEP: 60020-181, Fortaleza, CE, Brazil.

\section{Received: 13 March 2012 Accepted: 28 June 2012}

Published: 6 July 2012

\section{References}

1. Jemal A, Bray F, Center MM, Ferlay J, Ward E, Forman D: Global cancer statistics. CA Cancer J Clin 2011, 61(2):69-90.

2. Instituto Nacional de Câncer - INCA: Estimate/2010 - Incidence of Cancer in Brazil. Rio de Janeiro: Instituto Nacional de Câncer/Ministério da Saúde; 2009:98.

3. Correa P: Human gastric carcinogenesis: a multistep and multifactorial process-First American Cancer Society Award Lecture on Cancer Epidemiology and Prevention. Cancer Res 1992, 52(24):6735-6740.

4. Kim NW, Piatyszek MA, Prowse KR, Harley CB, West MD, Ho PL, Coviello GM, Wright WE, Weinrich SL, Shay JW: Specific association of human telomerase activity with immortal cells and cancer. Science 1994, 266(5193):2011-2015.

5. Artandi SE, DePinho RA: Mice without telomerase: what can they teach us about human cancer? Nat Med 2000, 6(8):852-855. 
6. Kyo S, Takakura M, Fujiwara T, Inoue M: Understanding and exploiting hTERT promoter regulation for diagnosis and treatment of human cancers. Cancer Sci 2008, 99(8):1528-1538.

7. Calcagno DQ, Leal MF, Assumpcao PP, Smith MA, Burbano RR: MYC and gastric adenocarcinoma carcinogenesis. World J Gastroenterol 2008, 14(39):5962-5968.

8. Fernandez PC, Frank SR, Wang L, Schroeder M, Liu S, Greene J, Cocito A, Amati B: Genomic targets of the human c-Myc protein. Genes Dev 2003, 17(9):1115-1129.

9. Dang CV, O'Donnell KA, Zeller Kl, Nguyen T, Osthus RC, Li F: The c-Myc target gene network. Semin Cancer Biol 2006, 16(4):253-264.

10. Szymanska K, Hainaut P: TP53 and mutations in human cancer. Acta Biochim Pol 2003, 50(1):231-238.

11. Vousden KH, Ryan KM: p53 and metabolism. Nat Rev Cancer 2009, 9(10):691-700

12. Khayat AS, Guimaraes AC, Calcagno DQ, Seabra AD, Lima EM, Leal MF, Faria MH, Rabenhorst SH, Assumpcao PP, Demachki S, et al: Interrelationship between TP53 gene deletion, protein expression and chromosome 17 aneusomy in gastric adenocarcinoma. BMC Gastroenterol 2009, 9:55.

13. Pelengaris S, Rudolph B, Littlewood T: Action of Myc in vivo - proliferation and apoptosis. Curr Opin Genet Dev 2000, 10(1):100-105.

14. Dazard JE, Piette J, Basset-Seguin N, Blanchard JM, Gandarillas A: Switch from p53 to MDM2 as differentiating human keratinocytes lose their proliferative potential and increase in cellular size. Oncogene 2000 19(33):3693-3705

15. Lan J, Xiong $Y Y$, Lin $Y X$, Wang BC, Gong LL, Xu HS, Guo GS: Helicobacter pylori infection generated gastric cancer through p53-Rb tumorsuppressor system mutation and telomerase reactivation. World J Gastroenterol 2003, 9(1):54-58.

16. Wang W, Luo HS, Yu BP: Expression of NF-kappaB and human telomerase reverse transcriptase in gastric cancer and precancerous lesions. World J Gastroenterol 2004, 10(2):177-181.

17. Cassaro M, Rugge M, Tieppo C, Giacomelli L, Velo D, Nitti D, Farinati F: Indefinite for non-invasive neoplasia lesions in gastric intestinal metaplasia: the immunophenotype. J Clin Pathol 2007, 60(6):615-621.

18. Gulmann C, Lantuejoul S, Grace A, Leader M, Patchett S, Kay E: Telomerase activity in proximal and distal gastric neoplastic and preneoplastic lesions using immunohistochemical detection of hTERT. Dig Liver Dis 2005, 37(6):439-445.

19. Jong HS, Park YI, Kim S, Sohn JH, Kang SH, Song SH, Bang YJ, Kim NK: Up-regulation of human telomerase catalytic subunit during gastric carcinogenesis. Cancer 1999, 86(4):559-565

20. Gigek CO, Leal MF, Silva PN, Lisboa LC, Lima EM, Calcagno DQ, Assumpcao PP, Burbano RR, Smith MA: hTERT methylation and expression in gastric cancer. Biomarkers 2009, 14(8):630-636.

21. Calcagno DQ, Leal MF, Demachki S, Araujo MT, Freitas FW: SD Oliveira e, Assumpcao PP, Ishak G, de Arruda Cardoso Smith M, Burbano RR: MYC in gastric carcinoma and intestinal metaplasia of young adults. Cancer Genet Cytogenet 2010, 202(1):63-66

22. Calcagno DQ, Leal MF, Seabra AD, Khayat AS, Chen ES, Demachki S, Assumpcao PP, Faria MH, Rabenhorst SH, Ferreira MV, et al: Interrelationship between chromosome 8 aneuploidy, C-MYC amplification and increased expression in individuals from northern Brazil with gastric adenocarcinoma. World J Gastroenterol 2006, 12(38):6207-6211

23. Costa Raiol LC, Figueira Silva EC, Mendes da Fonseca D, Leal MF, Guimaraes AC, Calcagno DQ, Khayat AS, Assumpcao PP, de Arruda Cardoso Smith M, Burbano RR: Interrelationship between MYC gene numerical aberrations and protein expression in individuals from northern Brazil with early gastric adenocarcinoma. Cancer Genet Cytogenet 2008, 181(1):31-35.

24. da Costa Jde F, Leal MF, Silva TC, Andrade Junior EF, Rezende AP, Muniz JA, Lacreta Junior AC, Assumpcao PP, Calcagno DQ, Demachki S, et al: Experimental gastric carcinogenesis in Cebus apella nonhuman primates. PLOS One 2011, 6(7):e21988.

25. Han JC, Zhang KL, Chen XY, Jiang HF, Kong QY, Sun Y, Wu ML, Huang L, Li H, Liu J: Expression of seven gastric cancer-associated genes and its relevance for Wnt, NF-kappaB and Stat3 signaling. APMIS 2007, 115(12):1331-1343

26. Yang GF, Deng CS, Xiong YY, Gong LL, Wang BC, Luo J: Expression of nuclear factor-kappa $B$ and target genes in gastric precancerous lesions and adenocarcinoma: association with Helicobactor pylori cagA ( + ) infection. World J Gastroenterol 2004, 10(4):491-496.

27. Zhang GX, Gu YH, Zhao ZQ, XU SF, Zhang HJ, Wang HD, Hao B: Coordinate increase of telomerase activity and c-Myc expression in Helicobacter pylori-associated gastric diseases. World J Gastroenterol 2004, 10(12):1759-1762

28. Assumpcao PP, Ishak G, Chen ES, Takeno SS, Leal MF, Guimaraes AC, Calcagno DQ, Khayat AS, Demachki S, Smith MA, et al: Numerical aberrations of chromosome 8 detected by conventional cytogenetics and fluorescence in situ hybridization in individuals from northern Brazil with gastric adenocarcinoma. Cancer Genet Cytogenet 2006, 169(1):45-49.

29. Burbano RR, Assumpcao PP, Leal MF, Calcagno DQ, Guimaraes AC, Khayat AS, Takeno SS, Chen ES, De Arruda Cardoso Smith M: C-MYC locus amplification as metastasis predictor in intestinal-type gastric adenocarcinomas: $\mathrm{CGH}$ study in Brazil. Anticancer Res 2006, 26(4B):2909-2914.

30. Calcagno DQ, Leal MF, Taken SS, Assumpcao PP, Demachki S, Smith Mde A, Burbano RR: Aneuploidy of chromosome 8 and C-MYC amplification in individuals from northern Brazil with gastric adenocarcinoma. Anticancer Res 2005, 25(6B):4069-4074.

31. Calcagno DQ, Guimaraes AC, Leal MF, Seabra AD, Khayat AS, Pontes TB, Assumpcao PP: De Arruda Cardoso Smith M, Burbano RR: MYC insertions in diffuse-type gastric adenocarcinoma. Anticancer Res 2009, 29(7):2479-2483.

32. Leal MF, Calcagno DQ: da Borges Costa JF, Silva TC, Khayat AS, Chen ES, Assumpcao PP, de Arruda Cardoso Smith M, Burbano RR: MYC, TP53, and chromosome 17 copy-number alterations in multiple gastric cancer cell lines and in their parental primary tumors. J Biomed Biotechnol 2011 2011:631268.

33. Leal MF: Nascimento JL Martins do, da Silva CE, Vita Lamarao MF, Calcagno DQ, Khayat AS, Assumpcao PP, Cabral IR, de Arruda Cardoso Smith M, Burbano RR: Establishment and conventional cytogenetic characterization of three gastric cancer cell lines. Cancer Genet Cytogenet 2009, 195:(1)85-91.

34. Ribeiro HF, Alcantara DF, Matos LA, Sousa JM, Leal MF, Smith MA, Burbano RR, Bahia MO: Cytogenetic characterization and evaluation of c-MYC gene amplification in PG100, a new Brazilian gastric cancer cell line. Braz J Med Biol Res 2010, 43(8):717-721.

35. Costa Guimaraes A, Goncalves Quintana L, Ferreira Leal M, Satomi Takeno S, Pimentel Assumpcao P, Moura Lima E, Salim Khayat A, Suchi Chen E, de Arruda Cardoso Smith M, Rodriguez Burbano R: Aneuploidy of chromosome 8 detected by fluorescence in situ hybridisation in ACP01 cell line gastric adenocarcinoma. Clin Exp Med 2006, 6(3):129-133.

36. Cesar AC, Borim AA, Caetano A, Cury PM, Silva AE: Aneuploidies, deletion, and overexpression of TP53 gene in intestinal metaplasia of patients without gastric cancer. Cancer Genet Cytogenet 2004, 153(2):127-132.

37. Morgan C, Jenkins GJ, Ashton T, Griffiths AP, Baxter JN, Parry EM, Parry JM: Detection of p53 mutations in precancerous gastric tissue. $\mathrm{Br} J$ Cancer 2003, 89(7):1314-1319.

38. Uchino S, Noguchi M, Ochiai A, Saito T, Kobayashi M, Hirohashi S: p53 mutation in gastric cancer: a genetic model for carcinogenesis is common to gastric and colorectal cancer. Int J Cancer 1993, 54(5):759-764

39. Shiao $Y H$, Rugge $M$, Correa P, Lehmann HP, Scheer WD: $p 53$ alteration in gastric precancerous lesions. Am J Pathol 1994, 144(3):511-517.

40. Wang J, Chi DS, Kalin GB, Sosinski C, Miller LE, Burja I, Thomas E: Helicobacter pylori infection and oncogene expressions in gastric carcinoma and its precursor lesions. Dig Dis Sci 2002, 47(1):107-113.

41. Targa AC, Cesar AC, Cury PM, Silva AE: Apoptosis in different gastric lesions and gastric cancer: relationship with Helicobacter pylori, overexpression of p53 and aneuploidy. Genet Mol Res 2007, 6(3):554-565

42. Williams L, Jenkins GJ, Doak SH, Fowler P, Parry EM, Brown TH, Griffiths AP, Williams JG, Parry JM: Fluorescence in situ hybridisation analysis of chromosomal aberrations in gastric tissue: the potential involvement of Helicobacter pylori. Br J Cancer 2005, 92(9):1759-1766.

43. Leal MF, Calcagno DQ: da Costa JF Borges, Silva TC, Khayat AS, Chen ES, Assumpcao PP, de Arruda Cardoso Smith M, Burbano RR: MYC, TP53, and chromosome 17 copy-number alterations in multiple gastric cancer cell lines and in their parental primary tumors. J Biomed Biotechnol 2010, 2011:631268.

44. Bacchi MM, Bacchi CE, Alvarenga M, Miranda R, Chen YY, Weiss LM: Burkitt's lymphoma in Brazil: strong association with Epstein-Barr virus. Mod Pathol 1996, 9(1):63-67. 
45. Clayton CL, Kleanthous H, Coates PJ, Morgan DD, Tabagchali S: Sensitive detection of Helicobacter pylori by using polymerase chain reaction. J Clin Microbiol 1992, 30(1):192-200.

46. Arocho A, Chen B, Ladanyi M, Pan Q: Validation of the 2-DeltaDeltaCt calculation as an alternate method of data analysis for quantitative PCR of BCR-ABL P210 transcripts. Diagn Mol Pathol 2006, 15(1):56-61.

doi:10.1186/1471-230X-12-85

Cite this article as: Silva et al:: hTERT, MYC and TP53 deregulation in gastric preneoplastic lesions. BMC Gastroenterology 2012 12:85.

\section{Submit your next manuscript to BioMed Central and take full advantage of:}

- Convenient online submission

- Thorough peer review

- No space constraints or color figure charges

- Immediate publication on acceptance

- Inclusion in PubMed, CAS, Scopus and Google Scholar

- Research which is freely available for redistribution 